\title{
IDENTIFIKASI BERPIKIR KRITIS MATEMATIKA SISWA KELAS X IPA-6 SMAK SANTO ALBERTUS MALANG
}

\author{
Flavia Aurelia Hidajat, I Nengah Parta dan Makbul Muksar \\ Universitas Negeri Malang \\ e-mail: makbul.muksar.fmipa@um.ac.id
}

\begin{abstract}
This research is meant to identify the critical thinking of X grade students of Science-class in SMAK Santo Albertus, Malang. Data of this research is collected from students test result related to critical thinking test as well as the result of interview done by the researcher with the teacher and students. Data analysis will be done after the treatment and all data are collected. Data analysis technique used in this research is flow model which includes data reduction, data presentation, conclusion and verification. Identification result of students' critical thinking of X grade in Science-6 class of SMAK Santo Albertus Malang shows that there are three levels in critical thinking, namely; students with Thinking level of "Critical", students with thinking level of "less critical", and students with thinking level of "Not critical". The result of this research provides information for teachers related to students' critical thinking, therefore, this research can give some reflection for the teacher in designing the next Mathematics teaching activities and help teacher in designing standard teaching development which improves students' critical thinking.
\end{abstract}

\section{Key Words: Thinking, Critical Thinking, and Students}

\begin{abstract}
Abstrak: Matematika merupakan mata pelajaran yang sangat memerlukan berpikir kritis dalam proses belajar siswa. Siswa perlu berpikir kritis untuk memikirkan dan memahami masalah dari berbagai sudut pandang. Sehigga berpikir kritis bukan sekedar proses menghafal, melainkan suatu proses yang dapat mengubah pola berpikir seseorang secara kritis dalam menghadapi suatu masalah. Mengingat pentingnya berpikir kritis, maka dalam penelitian akan di identifikasi berpikir kritis siswa kelas X IPA-6 SMAK Santo Albertus Malang. Data dalam penelitian ini adalah hasil pekerjaan siswa terkait tes berpikir kritis serta hasil wawancara peneliti dengan guru dan siswa. Analisis data akan dilakukan setelah pemberian tindakan dan semua data terkumpul. Teknik analisis data dalam penelitian ini adalah model alir (flow model) yang meliputi kegiatan reduksi data, penyajian data, dan penarikan kesimpulan dan verifikasi. Hasil identifikasi berpikir kritis siswa kelas X IPA-6 SMAK Santo Albertus Malang menunjukkan bahwa terdapat tiga tingkatan dalam berpikir kritis, yaitu siswa dengan tingkatan berpikir "kritis", siswa dengan tingkatan berpikir "kurang kritis", dan siswa dengan tingkatan berpikir "tidak kritis". Hasil penelitian ini dapat memberikan informasi kepada guru mengenai berpikir kritis siswa, sehingga penelitian ini dapat menjadi bahan refleksi bagi guru dalam merancang kegiatan pembelajaran matematika selanjutnya dan membantu guru dalam menetapkan tolak ukur pengembangan pembelajaran yang dapat meningkatkan berpikir kritis siswa.
\end{abstract}

Kata Kunci: berpikir, berpikir kritis, dan siswa

\section{PENDAHULUAN}

Matematika merupakan dasar dari ilmu pengetahuan dan mata pelajaran pokok yang diajarkan kepada semua peserta didik, mulai dari sekolah dasar hingga perguruan tinggi. Daryanto (2013: 411) mengatakan bahwa pelajaran matematika perlu diberikan kepada siswa mulai dari sekolah dasar untuk membekali siswa dalam berpikir kritis. Oleh karena itu, matematika dapat membantu siswa dalam berpikir kritis Hal ini 
juga berkorespondensi dengan suatu pernyataan yang mengatakan bahwa siswa yang mampu berpikir kritis dapat membantu siswa mempelajari pelajaran matematika secara mendalam dalam pembelajaran matematika.

Belajar matematika dalam pembelajaran matematika bukan merupakan suatu proses mengingat suatu materi atau masalah dalam pembelajaran matematika, melainkan proses perubahan cara berpikir seseorang terhadap suatu masalah dalam pembelajaran matematika (Dimyati \& Mudjiono, 2006: 11). Shen (2012) berpendapat bahwa pada saat belajar hafalan, siswa cenderung mengingat informasi dan hanya memusatkan perhatiannya dari permasalahan yang diberikan oleh guru. Oleh karena itu, siswa harus mempunyai keterampilan berpikir dalam memikirkan dan memahami masalah matematika dari berbagai sudut pandang. Badar (2015: 110) dan Stedman\&Adams (2012) menyatakan bahwa keterampilan berpikir dapat meningkatkan berpikir kritis yang membantu siswa untuk lebih memahami suatu masalah.

Berpikir kritis adalah salah satu bentuk berpikir tingkat tinggi yang digunakan dalam kehidupan sehari-hari. Brookfield (2012: 24) \& Epstein (2006:5) mendefinisikan berpikir kritis sebagai "susunan argumen yang mencakup beberapa alasan dan sebuah kesimpulan yang benar". Fisher (2009: 16) menyebutkan lima aspek berpikir kritis yaitu mengidentifikasi masalah, menemukan solusi, memberikan alasan, memeriksa kembali, dan memberikan kesimpulan. Kelima aspek ini akan digunakan sebagai evaluasi berpikir kritis siswa dalam penelitian ini.

Berpikir kritis penting digunakan dalam kehidupan sehari-hari. Berpikir kritis merupakan proses berpikir yang tidak hanya mengingat ataupun berpikir dasar yang sekedar memahami secara pasif me- lainkan proses berpikir yang ditandai dengan kemampuan mengalisa masalah, menentukan kecukupan data untuk menyelesaikan masalah, mengenali konsistensi data, dan menentu-kan kesimpulan dari sekumpulan data tersebut (Subanji, 2011: 5). Sani (2013: 223) mengatakan bahwa seseorang yang berpikir kritis tidak akan mudah percaya mengenai apapun yang di dengar atau di lihat; melainkan memperhatikan fakta yang ada untuk menentukan bukti yang mendukungnya serta mampu memberikan argumen dengan suatu alasan dan kesimpulan yang tepat. Sehingga, berpikir kritis ini merupakan proses berpikir yang perlu dikuasai siswa.

Pentingnya berpikir kritis ini mengakibatkan siswa perlu melibatkan berpikir kritis dalam setiap pembelajaran matematika. Sanjaya (2006: 107) berpendapat bahwa pada saat pembelajaran berpikir kritis, siswa tidak hanya menerima akumulasi pengetahuan materi tetapi siswa dituntut berpikir dan beragumen untuk mendukung suatu kesimpulan yang tepat. Pentingnya berpikir kritis ini juga didukung oleh Permendikbud No. 70 tahun 2013 tentang standar kompetensi lulusan pendidikan sekolah menengah atas dalam ranah keterampilan pola pikir, yaitu "menjadikan pola pembelajaran pasif menjadi pembelajaran yang dapat meningkatkan berpikir kritis siswa".

Berdasarkan pemaparan di atas mengenai pentingnya berpikir kritis, penelitian ini perlu dilakukan untuk mengetahui hasil identifikasi berpikir kritis siswa kelas X IPA-6 SMAK Santo Albertus Malang. Hasil penelitian ini diharapkan dapat menjadi bhaan refleksi guru dalam proses pembelajaran matematika yang selama ini telah berlangsung serta membantu guru dalam menetapkan tolak ukur pengembangan pem- 
belajaran yang sesuai dengan aturan Permendikbud No. 70 tahun 2013. Tolak ukur ini disesuaikan dengan aspek berpikir kritis yang digunakan dalam penelitian ini yaitu mengidentifikasi masalah, menemukan solusi, memberikan alasan, memeriksa kembali, dan memberikan alasan. Pada saat berpikir kritis siswa telah diketahui, selanjutnya guru perlu merancang kegiatan pembelajaran yang dapat memfasilitasi dan membiasakan siswa untuk berpikir kritis sehingga berpikir kritis siswa dapat meningkat.

\section{METODE}

Jenis penelitian ini adalah penelitian deskriptif dengan pendekatan kualitatif. Penelitian kualitatif adalah suatu penelitian yang mengungkapkan/mendeskripsikan fenomena, peristiwa, situasi sosial (obyek yang diteliti), sikap, dan kepercayaan, persepsi, pemikiran orang secara individual maupun kelompok (Sukmadinata, 2009: 60). Penelitian deskriptif menggambarkan uraian sistematis tentang teori dan hasil-hasil penelitian yang relevan dengan variabel yang diteliti (Sugiyono, 2010: 15).

Subyek penelitian adalah semua siswa kelas X-IPA 6 SMAK Santo Albertus Malang. Siswa kelas tersebut terdiri dari 36 siswa. Prosedur penelitian yang digunakan dalam penelitian ini adalah memberikan tes kepada semua siswa dan wawancara mendalam. Kegiatan wawancara ini dilakukan peneliti dengan guru serta empat orang siswa.
Instrumen pada penelitian ini adalah peneliti sendiri, tes berpikir kritis siswa dan rubrik penilaian tes, serta pedoman wawancara. Pada penelitian ini, peneliti berperan sebagai perencana, pengumpul, analisator, dan akhirnya pembuat laporan hasil penelitian. Tes berpikir kritis pada penelitian ini terdiri dari sebuah soal pada materi barisan dan deret. Tes yang digunakan telah dikonsultasikan dengan pembimbing. Selain itu, rubrik penilaian tes disesuaikan dengan kelima aspek berpikir kritis.

Data yang diperoleh dari tes dan wawancara akan dikumpulkan dan setelah itu di analisis. Teknik analisis data pada penelitian ini adalah model alir (flow model) yang dikemukakan oleh Miles dan Huberman (1984) yang meliputi kegiatan reduksi data, penyajian data dan penarikan kesimpulan dan verifikasi (Sugiono, 2010: 337). Kegiatan reduksi data pada penelitian ini adalah kegiatan menyeleksi, mengelompokkan, memfokuskan, dan menyederhanakan semua data mentah dan kasar yang diperoleh, baik data hasil tes dan wawancara. Kegiatan reduksi data hasil tes adalah menyesuaikan hasil tes siswa dengan rubrik penilaian berpikir kritis yang mencakup kelima aspek berpikir kritis dan kemudian mengelompokkan siswa ke dalam tingkatan berpikir kritis. Tingkatan berpikir kritis siswa disesuaikan dengan kelima aspek berpikir kritis dan ditunjukkan pada tabel 1.

Tabel 1. Tingkatan Berpikir Kritis

\begin{tabular}{ll}
\hline Tingkat berpikir & \multicolumn{1}{c}{ Karakteristik tingkat berpikir kritis } \\
\hline Kritis & - $\begin{array}{l}\text { Memaparkan masalah sesuai dengan fokus pertanyaan dengan jelas, sehingga } \\
\text { dapat menentukan alur penyelesaian }\end{array}$ \\
& - $\begin{array}{l}\text { masalah yang tepat dalam menyelesaikan masalah } \\
\text { - }\end{array}$ \\
& mengetahui solusi/ cara yang tepat dalam menyelesaikan masalah sehingga \\
& memberikan penyelesaian masalah dengan tepat \\
& suatu masalah matematika yang tepat untuk mendukung kesimpulan dari \\
- Memberikan penyelesaian masalah dengan teliti \\
- Merangkai alasan-alasan untuk memberikan kesimpulan, sehingga menarik \\
\end{tabular}




\begin{tabular}{|c|c|}
\hline Cukup kritis & $\begin{array}{l}\text { - Memaparkan masalah sesuai dengan fokus pertanyaan dengan jelas, sehingga } \\
\text { dapat menentukan alur penyelesaian } \\
\text { - masalah yang tepat dalam menyelesaikan masalah } \\
\text { - Sedikit mengetahui solusi/ cara dalam menyelesaikan masalah, sehingga } \\
\text { memaparkan penyelesaian masalah dengan kurang tepat } \\
\text { - Memberikan alasan-alasan yang kurang tepat untuk mendukung kesimpulan dari } \\
\text { suatu masalah matematika. } \\
\text { - Memberikan penyelesaian masalah dengan kurang teliti } \\
\text { - Merangkai alasan-alasan untuk memberikan kesimpulan, sehingga menarik } \\
\text { suatu kesimpulan yang tepat }\end{array}$ \\
\hline Kurang kritis & $\begin{array}{l}\text { - Memaparkan masalah sesuai dengan fokus pertanyaan dengan jelas, sehingga } \\
\text { dapat menentukan alur penyelesaian masalah yang tepat dalam menyelesaikan } \\
\text { masalah } \\
\text { - Tidak menemukan solusi/ cara dalam menyelesaikan masalah sehingga } \\
\text { tidak mampu menyelesaikan masalah } \\
\text { - Tidak memberikan alasan-alasan untuk mendukung kesimpulan yang dibuat } \\
\text { berdasarkan masalah matematika yang diberikan. } \\
\text { - Memberikan penyelesaian masalah dengan tidak teliti } \\
\text { - Tidak mampu memberikan kesimpulan }\end{array}$ \\
\hline Tidak kritis & $\begin{array}{l}\text { - Memaparkan masalah yang tidak sesuai dengan fokus pertanyaan, sehingga } \\
\text { menentukan alur penyelesaian masalah yang tidak tepat dalam menyelesaikan } \\
\text { masalah } \\
\text { - Tidak menemukan solusi/ cara dalam menyelesaikan masalah sehingga } \\
\text { tidak mampu menyelesaikan masalah } \\
\text { - Tidak memberikan alasan-alasan untuk mendukung kesimpulan yang dibuat } \\
\text { berdasarkan masalah matematika } \\
\text { - yang diberikan. } \\
\text { - Memberikan penyelesaian masalah dengan tidak teliti } \\
\text { - Tidak mampu memberikan kesimpulan }\end{array}$ \\
\hline
\end{tabular}

Sedangkan, kegiatan reduksi data wawancara adalah menyederhanakan hasil wawancara, baik wawancara dengan guru maupun siswa. Kegiatan mengana-lisis selanjutnya adalah menyajikan data. Kegiatan penyajian data pada penelitian ini adalah kegiatan menyajikan hasil reduksi data ke dalam bentuk naratif sehingga memungkinkan penarikan ke-simpulan dan keputusan pengambilan tindakan. Data yang telah disajikan tersebut kemudian dibuat penafsiran dan evaluasi. Kegiatan akhir dalam analisi data yaitu penarikan kesimpulan dan verifikasi. Kegiatan penarikan kesimpulan dan verifikasi adalah kegiatan memberikan kesimpulan terhadap hasil penafsiran dan evaluasi.

\section{HASIL DAN PEMBAHASAN}

Kegiatan awal yang dilakukan dalam penelitian ini adalah memberikan tes berpikir kritis kepada siswa. Tes ini bertujuan untuk mengetahui dan mendukung identifikasi berpikir kritis siswa kelas $\mathrm{X}$ IPA-6 SMAK Santo Albertus Malang. Soal tes berpikir kritis ditunjukkan pada Gambar 1.

\section{Perhatikan pola bilangan berikut!}

$$
1, \frac{1}{2}, \frac{1}{4}, \ldots
$$

Tentukan suku ke-10? berikan alasanmu! 


\section{Gambar 1. Pertanyaan permasalahan}

Berdasarkan tes tersebut, 36 siswa kelas X IPA-6 SMAK Santo Albertus Malang terbagi menjadi 3 tingkatan berpikir kritis yaitu sembilan siswa berada tingkatan berpikir "kritis", empat siswa berada pada tingkatan berpikir "kurang kritis", dan dua puluh tiga siswa lainnya berada pada tingkatan berpikir "tidak kritis".

\section{Tingkatan berpikir "kritis"}

Kesembilan siswa yang berada pada tingkatan "kritis" telah mampu memenuhi kelima aspek berpikir kritis. Hal ini ditunjukkan pada hasil tes kesembilan siswa ini yang mampu memaparkan masalah sesuai dengan fokus pertanyaan dengan jelas, sehingga dapat menentukan alur penyelesaian masalah yang tepat dalam menyelesaikan masalah, mampu mengetahui solusi/cara yang tepat dalam menyelesaikan masalah sehingga memaparkan penyelesaian masalah dengan tepat, memberikan alasan-alasan yang tepat untuk mendukung kesimpulan dari suatu masalah pada gambar 1, memberikan penyelesaian masalah dengan teliti, dan mampu merangkai alasan-alasan untuk memberikan kesimpulan, sehingga menarik suatu kesimpulan yang tepat satu dari sembilan siswa pad tingkatan ini berinisial JWN. JWN mampu memaparkan masalah sesuai dengan fokus pertanyaan dengan jelas, sehingga dapat menentukan alur penyelesaian masalah yang tepat dalam menyelesaikan masalah. JWN juga dapat menemukan solusi yang tepat dalam menyelesaikan masalah. Hal ini ditunjukkan pada gambar 2.

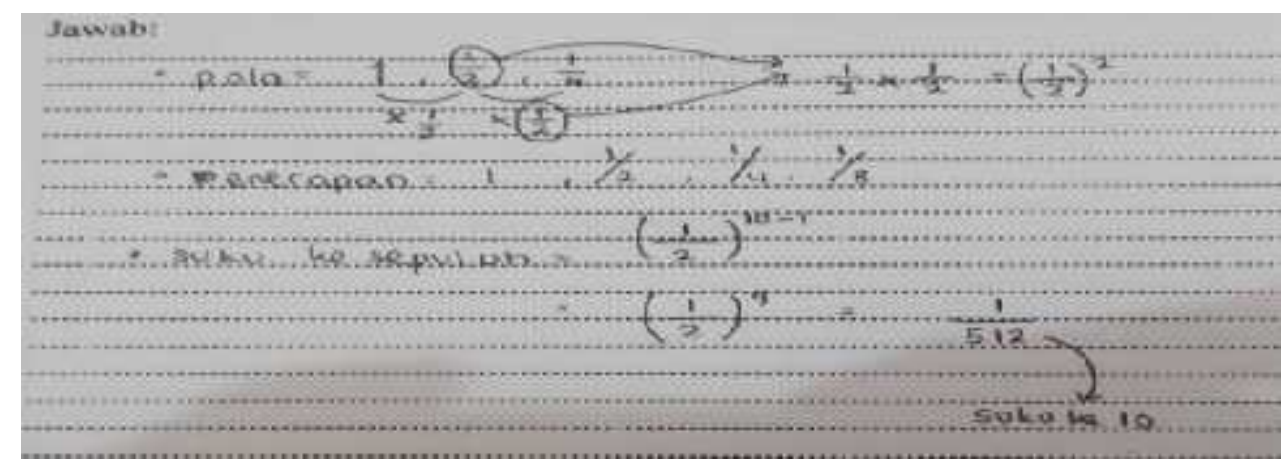

Gambar 2. Hasil pekerjaan JWN terkait aspek "menemukan solusi"

Gambar 2 menunjukkan bahwa JWN Penemuan solusi jawaban ini juga dimencoba menemukan pola bilangannya. dukung oleh JWN dengan memberikan Berdasarkan pola umum yang ditemu- alasan yang tepat. Hasil pekerjaan JWN kannya, JWN dapat menemukan solusi terkait dengan aspek "memberikan alasan" jawaban yang tepat dengan memasukkan ditunjukkan pada gambar 3 berikut. suku ke-10 pada pola bilangan tersebut. 


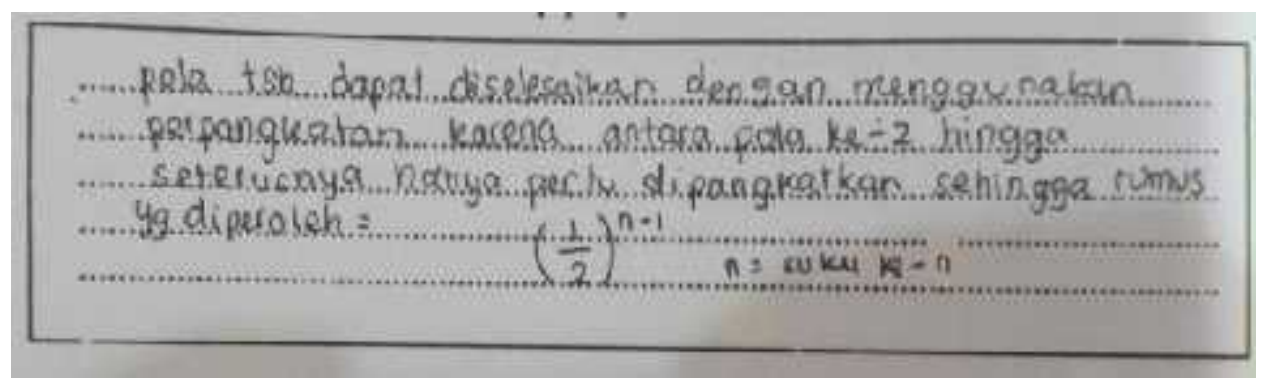

Gambar 3. Hasil pekerjaan JWN terkait aspek "memberikan alasan"

Pada Gambar 3, JWN memberikan alasan dengan menemukan pula suatu pola bilangan. Hal ini juga di dukung dari hasil wawancara dengan JWN yaitu "Berdasarkan perma-salahan ini, pola umum yang diperoleh adalah suku ke- $n$ yaitu $U_{n}=\left(\frac{1}{2}\right)^{n-1}$. Oleh karena itu, JWN mampu memberikan alasan yang tepat untuk mendukung kesimpulan dari suatu permasalahan. JWN juga dapat menyelesaikan masalah dengan cermat dan teliti, sehingga JWN memberikan kesimpulan yang tepat terhadap pertanyaan permasalahan pada gambar 1. Pada aspek "memberikan kesimpulan", JWN dapat menarik suatu kesimpulan yang tepat.

\section{Tingkatan berpikir "kurang kritis"}

Terdapat empat siswa ini sudah mampu memaparkan masalah sesuai dengan fokus pertanyaan dengan jelas, namun belum mampu memenuhi keempat aspek berpikir kritis lainnya yaitu menemukan solusi, memberikan alasan, memeriksa kembali hasil pekerjaannya secara cermat dan teliti, serta memberikan kesimpulan; Salah satu siswa dari keempat siswa ini adalah CJH. Hasil pekerjaan $\mathrm{CJH}$ terkait aspek "mengidentifikasi masalah" dapat ditunjukkan pada gambar 4.

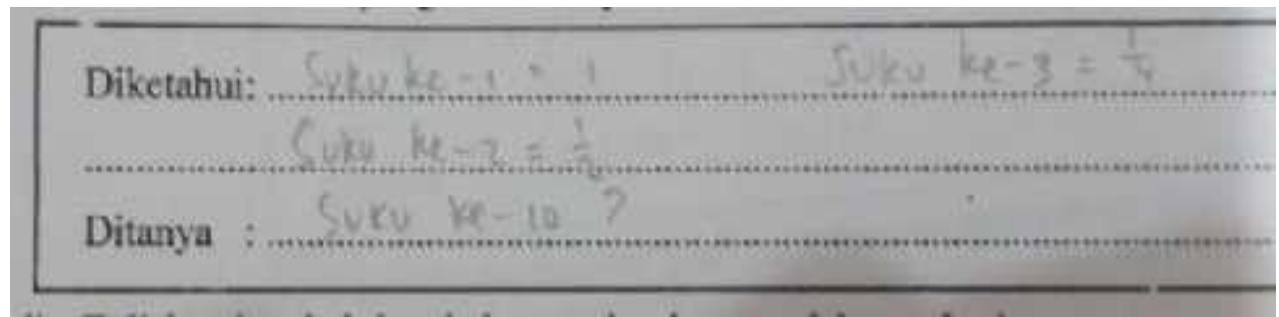

Gambar 4. Hasil pekerjaan CJH terkait aspek "mengidentifikasi masalah"

Gambar 4 merupakan hasil masalah yang tepat dalam menyelesaikan pekerjaan siswa berinisial CJH. CJH masalah. Namun, CJH belum menemukan mampu memaparkan masalah sesuai dengan solusi jawaban yang tepat dalam fokus pertanyaan dengan jelas, sehingga menyelesaikan permasalahan tersebut. Hal dapat menentukan alur penyelesaian ini ditunjukkan pada gambar 5. 


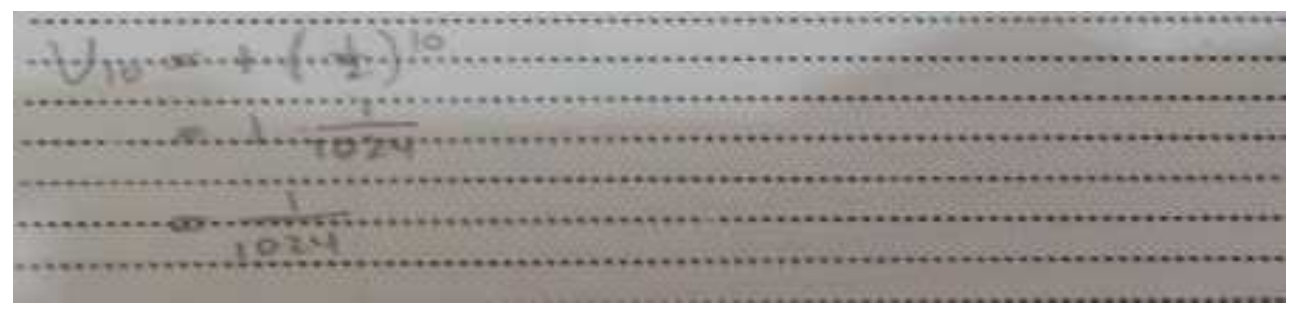

Gambar 5. Hasil pekerjaan CJH terkait aspek "menemukan solusi"

Gambar 5 diatas terlihat bahwa CJH lang-sung memasukkan $n=10$ ke dalam rumus suku ke- $n$ terhadap barisan geometri dalam menyelesaikan permasalahan tersebut. Pada pertanyaan permasalahan tidak memapar-kan bahwa barisan tersebut adalah barisan geometri, tetapi CJH menentukan suku ke-10 dengan menggunakan rumus suku ke- $n$ terhadap barisan geometri. Hal ini juga di dukung oleh hasil wawancara dengan $\mathrm{CJH}$ yang mengatakan bahwa, "barisan ini merupakan barisan geometri". CHJ juga salah menentukan rumus suku ke$n$ terhadap barisan geometri sehingga juga tidak dapat menemukan suku ke-10.

Ketidakmampuan siswa dalam menemukan solusi jawaban yang tepat mengakibatkan siswa tidak dapat memberikan alasan yang tepat untuk mendukung kesimpulan dari permasalahan tersebut. Berdasarkan hasil pekerjaan siswa terkait aspek "memberikan alasan", CJH mengatakan bahwa "karena barisan pada pertanyaan permasalahan adalah barisan geometri dengan rasio $(r)=$ $1 / 2$, maka hasilnya juga menggunakan rumus suku ke-n terhadap barisan geometri. Hal ini juga didukung dari hasil wawancara dengan CJH yaitu "Berdasarkan apa yang sudah saya pelajari, barisan ini merupakan barisan geometri". Oleh karena itu, CJH tersebut tidak mampu memberikan alasan yang tepat untuk mendukung kesimpulan dari suatu permasalahan. $\mathrm{CJH}$ juga tidak mampu memeriksa kembali hasil pekerjaannya dengan cermat dan teliti, sehingga siswa memberikan kesimpulan yang tidak tepat terhadap pertanyaan permasalahan pada gambar 1. Hasil pekerjaan $\mathrm{CJH}$ terkait dengan aspek "memberikan kesimpulan" ditunjukkan pada gambar 6 berikut.

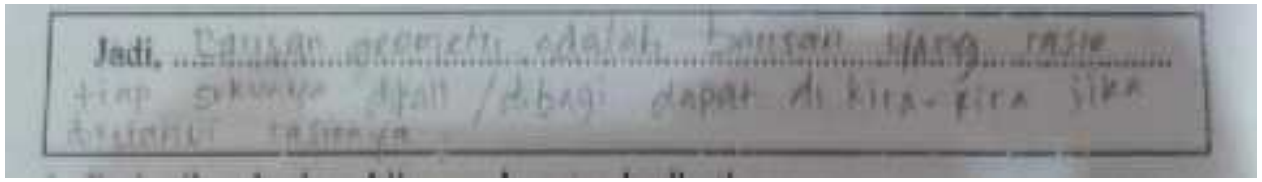

Gambar 6. Hasil pekerjaan CJH terkait aspek "memberikan kesimpulan"

\section{Tingkatan berpikir "tidak kritis"}

Kedua puluh tiga siswa lainnya yang berada pada tingkatan "tidak kritis" tidak mampu memenuhi kelima aspek berpikir kritis. Salah satu siswa dari kedua puluh tiga siswa ini adalah siswa yang berinisia PVA. PVA tidak memberikan pemamparan masalah yang sesuai dengan fokus pertanyaan permasalahan pada tes tersebut, sehingga tidak dapat menentukan alur penyelesaian permasalahan dengan tepat. Hasil pekerjaan PVA terkait dengan aspek "mengidentifikasi masalah" ditunjukkan pada gambar 7.

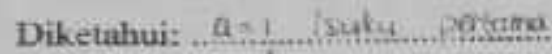
(resio) $r=\frac{1}{2}$.

Ditanya :...5ukm...4h.....18 


\section{Gambar 7. Hasil pekerjaan PVA terkait aspek "mengidentifikasi masalah"}

Pada Gambar 7, PVA menuliskan hal yang diketahui yaitu suku pertama $(a)=1$ dan rasio $(r)$ $=1 / 2$ serta hal yang ditanya yaitu suku ke-10. Siswa menuliskan hal yang diketahui dan ditanya, tetapi hal yang diketahui tersebut tidak fokus pada pertanyaan permasalahan yang ada. Pada pertanyaan permasalahan tidak memaparkan bahwa barisan tersebut selalu mempunyai rasio $(r)=1 / 2$, tetapi siswa tersebut menuliskan bahwa barisan tersebut mem- punyai rasio $(r)=1 / 2$ Selain itu, siswa hanya menuliskan suku pertamanya saja dan tidak menuliskan suku-suku lainnya yang diketahui pada permasalahan tersebut.

PVA juga belum menemukan solusi jawaban yang tepat dalam menyelesaikan permasalahan tersebut. Hal ini ditunjukkan pada hasil pekerjaan salah satu siswa dalam gambar 8 berikut. 



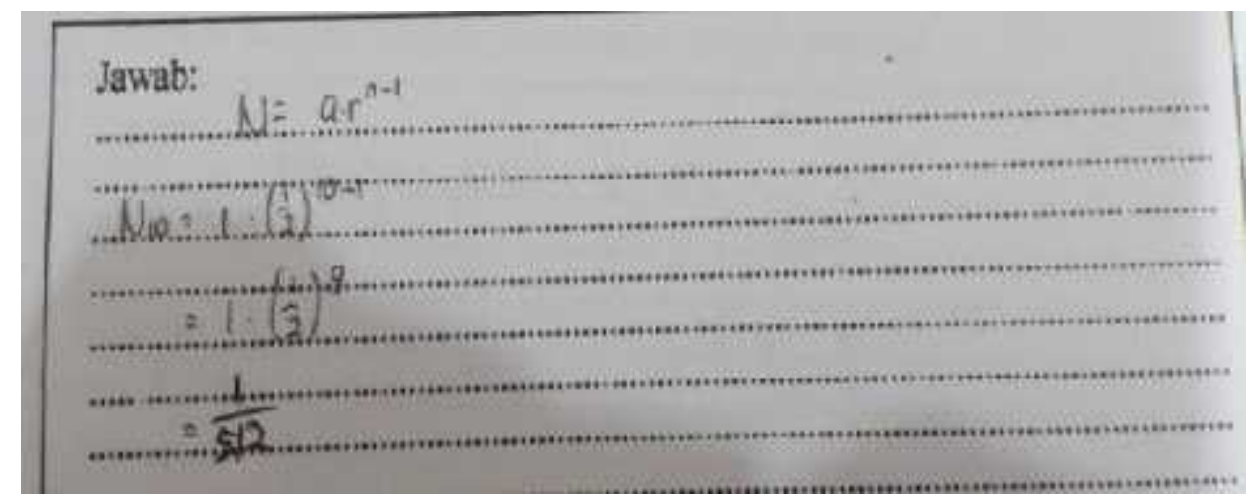

Gambar 8. Hasil pekerjaan PVA terkait aspek "menemukan solusi"

Gambar 8 diatas menunjukkan bahwa PVA langsung menggunakan rumus suku ke- $n$ terhadap barisan geometri, yaitu $N=$ $a r^{n}$ dalam menyelesaikan permasalahan tersebut. Pada pertanyaan permasalahan tidak memaparkan bahwa barisan tersebut adalah barisan geometri, tetapi PVA menentukan suku ke-10 dengan menggunakan rumus suku ke- $n$ terhadap barisan geometri. Hal ini juga di dukung oleh hasil wawancara dengan PVA yang mengatakan bahwa,"barisan ini adalah barisan geometri, karena dari suku pertama ke suku berikutnya dan ke suku berikutnya lagi selisihnya bukan ditambah ataupun dikurangi tetapi dikalikan atau dibagi”. Ketidakmampuan PVA dalam menemukan solusi jawaban yang tepat mengakibatkan PVA tidak dapat memberikan alasan yang tepat untuk mendukung kesimpulan dari permasalahan tersebut. Hasil pekerjaan PVA terkait dengan aspek "memberikan alasan" ditunjukkan pada gambar 9 berikut.

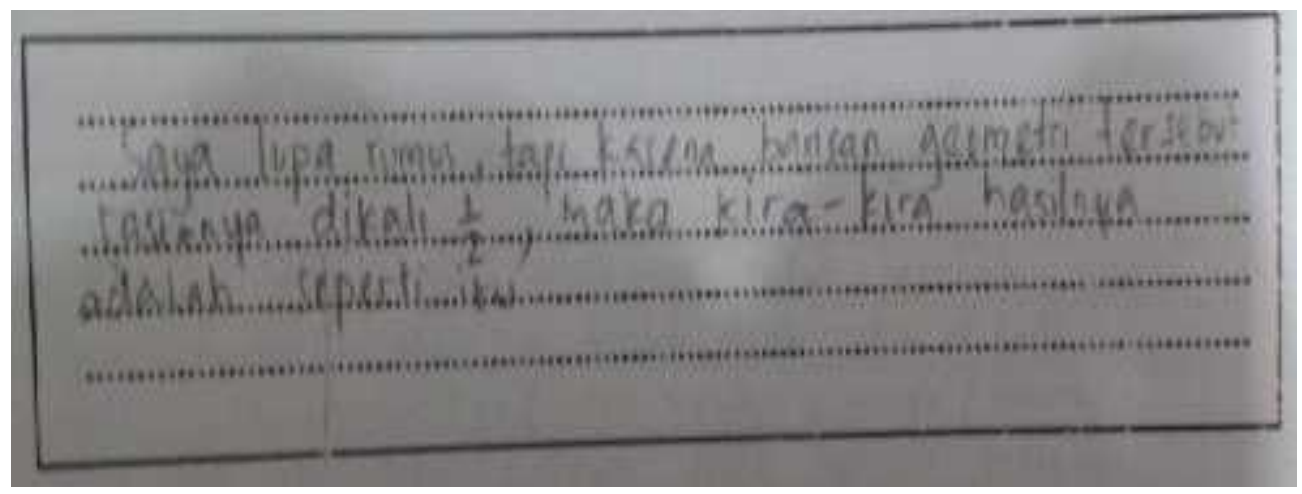

Gambar 9. Hasil pekerjaan PVA terkait aspek "memberikan alasan"

Pada Gambar 9, PVA memberikan alasan bahwa "karena barisan pada pertanyaan permasalahan adalah barisan geometri dengan rasio $(r)=1 / 2$, maka hasilnya juga menggunakan rumus suku ke- $n$ terhadap barisan geometri. Hal ini juga didukung dari hasil wawancara dengan PVA yaitu "Berdasarkan apa yang sudah saya pelajari, barisan ini merupakan barisan geometri". Oleh karena itu, PVA tersebut tidak mampu memberikan alasan yang tepat untuk mendukung kesimpulan dari suatu permasalahan. PVA juga tidak mampu memeriksa kembali hasil pekerjaannya dengan cermat dan teliti, sehingga PVA memberikan kesimpulan yang 
tidak tepat terhadap pertanyaan permasalahan pada gambar 1. Hasil pekerjaan PVA terkait dengan aspek "memberikan kesimpulan" ditunjukkan pada gambar 10 berikut

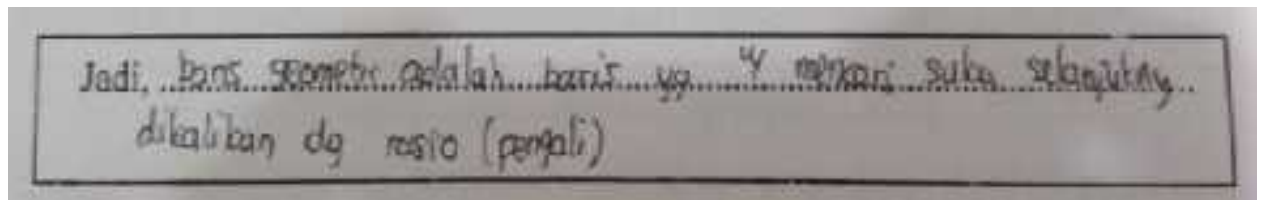

Gambar 10. Hasil pekerjaan PVA terkait aspek "memberikan kesimpulan"

Berdasarkan hasil pekerjaan siswa terkait tes berpikir kritis, hanya 9 dari 36 siswa yang mampu berpikir kritis, 4 dari 36 siswa kurang mampu berpikir kritis, dan 23 dari 36 siswa lainnya tidak mampu berpikir kritis. Berdasarkan fakta-fakta yang dipaparkan diatas tampak bahwa sebagaian besar siswa kelas X IPA-6 belum mampu untuk berpikir kritis. Ketidakmampuan siswa dalam berpikir kritis disebabkan oleh bebrapa faktor. Salah satu faktor ketidakmampuan siswa dalam berpikir kritis adalah pembelajaran di kelas yang belum mendorong siswa untuk berpikir kritis. Hal ini di buktikan pada hasil wawancara guru dengan tiga orang siswa. Hasil wawancara antara penulis dengan guru bidang studi matematika menyatakan bahwa pembelajaran yang dilakukan guru masih menggunakan metode pembelajaran ceramah dan membantu siswa untuk menggunakan rumus dalam perhitungan matematika. Selain itu, guru juga belum mengetahui pengertian berpikir kritis. Hal ini dibuktikan dengan pernyataan guru yang mengatakan bahwa "Beberapa siswa sudah mampu berpikir kritis dengan cara menjawab setiap perta-nyaan yang diberikan oleh guru sesuai dengan penjelasan yang diberikan". Sedangkan hasil wawancara dengan siswa mengatakan bahwa mereka selalu mendapat rumus-rumus cepat untuk memudahkan penyelesaian masalah dalam latihan soal dan tugas rumah. Berdasarkan penelitian ini, peneliti menemukan beberapa temuan yaitu: 1) terdapat 9 dari 36 siswa yang mampu berpikir kritis. Kesembilan siswa ini mampu memaparkan masalah sesuai dengan fokus pertanyaan dengan jelas, menemukan solusi yang tepat dalam menyelesaikan masalah dan memberikan alasan-alasan yang tepat, memeriksa kembali hasil pekerjaaanya dengan cermat dan teliti, serta memberikan kesimpulan yang tepat pula; 2) 4 dari 36 siswa yang kurang mampu berpikir kritis. Keempat siswa sudah mampu memaparkan masalah sesuai dengan fokus pertanyaan dengan jelas, namun belum mampu memenuhi keempat aspek berpikir kritis lainnya yaitu menemukan solusi, memberikan alasan, memeriksa kembali hasil pekerjaannya secara cermat dan teliti, serta memberikan kesimpulan; 3) 23 dari 36 siswa yang tidak mampu berpikir kritis. Kedua puluh tiga siswa ini belum mampu memenuhi keempat aspek berpikir kritis dalam hasil tesnya yaitu siswa belum mampu me-maparkan masalah yang sesuai dengan fokus pertanyaan dengan jelas, menemukan solusi, memberikan alasan, memeriksa kembali hasil pekerjaannya secara cermat dan teliti, serta memberikan kesimpulan.

\section{SIMPULAN}

Berdasarkan hasil penelitian dan pembahasan yang telah diuraikan dapat disimpulkan bahwa (1) Identifikasi berpikir kritis siswa kelas X IPA-6 SMAK Santo Albertus Malang menunjukkan ada tiga tingkatan dalam berpikir kritis, yaitu siswa dengan tingkatan berpikir "kritis", siswa dengan tingkatan berpikir "kurang kritis", dan siswa dengan tingkatan berpikir "tidak kritis".(2) Siswa dengan tingkatan berpikir 
"kritis" ditunjukkan dengan kemampuan siswa dalam memaparkan masalah sesuai dengan fokus pertanyaan dengan jelas, mampu menemukan solusi yang tepat dalam menyelesaikan masalah, memberikan alasanalasan yang tepat, teliti, serta memberikan kesimpulan yang tepat. (3) Siswa dengan tingkatan berpikir "kurang kritis" ditunjukkan dengan kemampuan siswa dalam memaparkan masalah sesuai dengan fokus pertanyaan dengan jelas, namun belum mampu menemukan solusi yang tepat dalam menyelesaikan

\section{DAFTAR PUSTAKA}

Badar, Trianto Ibnu. 2015. Mendesain Model Pembelajaran Inovatif, Progesif dan Kontekstual: Prenada media group

Brookfield, Stephen. 2012. Teaching For Critical Thinking. America: Jossey Bass

Daryanto. 2013. Inovasi Pembelajaran Efektif. Bandung: Yrama Widya.

Dimyati \& Mudjiono. 2006. Belajar dan Pembelajaran. Jakarta: Rineka Cipta.

Epstein, Richard L. 2006. Critical Thinking. Canada: Thomson Wadsworth

Fisher, Alec. 2009. Berpikir Kritis: Sebuah Pengantar. Jakarta: Erlangga.

Ngalimun. 2012. Strategi dan Model Pembelajaran. Banjarmasin: Aswaja Pressindo

Sani, Ridwan Abdullah. 2013. Inovasi Pembelajaran. Jakarta: Bumi Aksara.

Sanjaya, Wina. 2006. Strategi Pembelajaran Berorientasi Standar Proses Pendidikan. Jakarta: Kencana Prenada Media.

Shen, Ping. 2012. A Case Study of Teacher's Questioning and Students' Critical Thinking in College EFL Reading Classroom. International masalah, belum memberikan alasan-alasan yang tepat, tidak teliti serta tidak memberikan kesimpulan yang tepat. (4) Siswa dengan tingkatan berpikir "tidak kritis" ditunjukkan dengan ketidakmampuan siswa dalam memaparkan masalah sesuai dengan fokus pertanyaan, menemukan solusi masalah, memberikan alasan-alasan dengan tepat, memeriksa kembali hasil pekerjaannya dan memberikan kesimpulan yang tepat.

Journal of English Linguistics, (Online), 2 (1): 199-206, (http:// scholar.google.co.id), diakses 16 Januari 2015

Stedman, Nicole L.P \& Adams, Brittany L. 2012. Identifying Faculty's Knowledge of Critical Thinking Concepts and Perceptions of Critical Thinking Instruction in Higher Education. Journal of International Students, (Online), 56 (2): 9-14, (http://web.b. ebscohost.com/abstract), diakses 16 Januari 2015.

Subanji. 2011. Teori Berpikir Pseudo Penalaran Kovariasional. Malang: Universitas Negeri Malang (UM PRESS).

Sugiyono. 2010. METODE PENELITIAN PENDIDIKAN: Pendekatann Kuantitatif, kualitatif, dan $R \& D$. Bandung: Alfabeta.

Sukmadinata, Nana Syaodih. 2009. Metode Penelitian Pendidikan. Bandung: Remaja Rosdakarya 

112 Jurnal Ilmiah Pendidikan Matematika, Vol. 4 No. 2, flm 100-110 
. 
114 Jumal Ilmiah Pendidikan Matematika, Vol. 4 No. 2, hlm 100-110 